\title{
Pengembangan Perangkat Kooperatif Tipe NHT Berbasis Pendekatan Ilmiah pada Materi Asam Basa untuk Meningkatkan Sikap Ilmiah dan Hasil Belajar Kognitif Peserta Didik
}

\author{
Hasnawiyah Hasnawiyah \\ Pendidikan Kimia, Universitas Negeri Makassar \\ Email: hasnawiyahnanna@gmail.com \\ Muhammad Danial \\ Pendidikan Kimia, Universitas Negeri Makassar \\ Email: muhammaddanial@yahoo.com \\ Wahidah Sanusi \\ Pendidikan Matematika, Universitas Negeri Makassar \\ Email: wahidah.sanusi@unm.ac.id
}

(Diterima: 11-Januari-2021; direvisi: 12-Februari-2021; dipublikasikan: 29-Maret-2021)

\begin{abstract}
Abstrak: Penggunaan perangkat yang tepat sangat menentukan keberhasilan pencapaian kompetensi peserta didik dalam pembelajaran. Perangkat pembelajaran yang cenderung monoton membuat peserta didik kurang terlibat aktif dalam pembelajaran dan kurang meningkatkan sikap ilmiah dan hasil belajar peserta didik. Pengembangan perangkat pembelajaran kimia berbasis pendekatan ilmiah dalam model NHT diharapkan efektif diterapkan dalam kelas dan membantu peserta didik dalam pembelajaran kimia. Penelitian pengembangan ini bertujuan untuk; 1) Mendeskripsikan proses pengembangan menghasilkan perangkat pembelajaran kooperatif tipe NHT berbasis pendekatan ilmiah; dan 2). Menghasilkan perangkat pembelajaran kooperatif tipe NHT berbasis pendekatan ilmiah yang valid, praktis, dan efektif untuk meningkatkan sikap ilmiah dan hasil belajar peserta didik pada materi asam basa. Penelitian ini terdiri dari tahap pendefenisian (define), perancangan (design), pengembangan (development), dan penyebaran (disseminate). Produk yang dikembangkan diujicobakan pada peserta didik kelas XI MIPA.3 SMA Negeri 8 Gowa Tahun pelajaran 2019/2020. Kevalidan produk diuji oleh dua orang validator ahli. Penelitian ini meliputi langkah-langkah model NHT yaitu persiapan, pembentukan kelompok, diskusi masalah, memanggil Nomor Anggota atau Pemberian Jawaban, memberi Kesimpulan, dan memberikan penghargaan. Tahapan perangkat pembelajaran kimia ini juga mengacu pada pendekatan sikap ilmiah yang menerapkan 5M yaitu mengamati, menanya, mencoba, mangasosiasi/mangolah informasi/manalar dan mengomunikasikan untuk meningkatkan sikap ilmiah dan hasil belajar peserta didk. Hasil penelitian diperoleh; 1) rata-rata nilai kevalidan produk 3,76 (sangat valid); 2) data angket sikap ilmiah $\overline{\mathrm{X}}=3,07$ (tinggi); 3) hasil rata-rata $\mathrm{N}$ Gain THB adalah 0,83 (tinggi); 4) Guru dan peserta didik menunjukkan respon yang sangat positif dengan persentase $95,84 \%$ dan $82,81 \%$. Hal ini dapat disimpulkan bahwa perangkat pembelajaran kimia berbasis pendekatan ilmiah dalam model NHT yang telah dikembangkan dalam pembelajaran kimia materi asam basa valid, praktis, dan efektif untuk meningkatkan sikap ilmiah dan hasil belajar peserta didik.
\end{abstract}

Kata kunci: NHT; Sikap Ilmiah; Hasil Belajar Kimia.

Abstract: The use of the right tools greatly determines the success of achieving the competence of students in learning. Learning tools that tend to be monotonous make students 
less actively involved in learning and less improve scientific attitudes and learning outcomes. The development of Chemistry learning tools based on a scientific approach in NHT model is expected to be effective in the classroom and help students in learning Chemistry. This development research aims to: 1) describe the development process of producing cooperative learning tools of NHT type based on a scientific approach; and 2) produce cooperative learning tools of NHT type based on scientific approaches that are valid, practical, and effective to improve scientific attitudes and learning outcomes on Acid-Base learning material. This research consists of the stages of defining (define), design, development, and dissemination (disseminate). The product developed was tested on students of class XI MIPA.3 at SMAN 8 Gowa of academic year 2019/2020. The product validity was tested by two expert assessors. This research includes the steps of the NHT model, namely preparation, group formation, problem discussion, calling the Member Number or Giving Answers, giving conclusions, and giving awards. The stages of this chemistry learning tool also refer to the scientific attitude approach that applies 5M, namely observing, asking, trying, associating/processing information/logic,and communicating to improve scientific attitudes and learning outcomes of students. The results of the study obtained: 1) the average value of product validity 3.76 (very valid); 2) scientific attitude questionnaire data $=3.07$ (high); 3) THB's average N-Gain result is 0.83 (high); 4) teachers and students showed a very positive response with a percentage of $95.84 \%$ and $82.81 \%$. Therefore, the conclusion of the study is the Chemistry learning tools based on the scientific approach in NHT model that had been developed in Chemistry learning on Acid-Base learning materials are valid, practical, and effective to improve the scientific attitude and learning outcomes of students.

Keywords: NHT; Scientific Attitude; Chemistry Learning Outcomes.

\section{PENDAHULUAN}

Pendidikan merupakan aspek yang sangat penting dalam menunjang kemajuan bangsa di masa depan. Dunia pendidikan semakin hari terus mengadakan perbaikan kejenjang yang lebih baik, namun langkah menuju perbaikan itu tidaklah mudah, banyak hal yang harus diperbaiki salah satunya ialah mempersiapkan kualitas sumber daya manusia (SDM). Pendidikan adalah aset masa depan dalam membentuk SDM yang berkualitas (Sobry, 2006).

Pembangunan di bidang pendidikan diarahkan kepada pengembangan sumber daya manusia yang bermutu tinggi untuk memenuhi kebutuhan dan menghadapi tantangan kehidupan di masa depan. Begitu juga halnya Indonesia menempatkan pendidikan sebagai sesuatu yang penting dan utama. Hal ini dapat dilihat dari isi pembukaan Undang-Undang Dasar Negara Republik Indonesia 1945, alinea IV yang menegaskan bahwa salah satu tujuan nasional bangsa Indonesia adalah mencerdaskan kehidupan bangsa.
Program pendidikan memiliki pengaruh yang besar dalam melejitkan SDM yang dimiliki setiap peserta didik. Oleh karena itu, pendidikan bertanggung jawab penuh dalam peningkatan SDM melalui pembentukan pola pikir yang baik bagi peserta didik. Tak salah jika pendidikan menjadi fokus utama yang patut kita perhatikan dalam membangun peradaban bangsa. Tercapainya pendidikan yang baik mampu melatih, membentuk, mengembangkan, dan mencetak kompetensi yang handal dalam bidang yang digeluti peserta didik. Menurut Purwanto \& Nugroho (2018) bahwa pendidikan nasional bertujuan mengembangkan dan membentuk watak serta peradaban bangsa yang bermartabat dalam rangka mencerdaskan kehidupan bangsa.

Salah satu SDM yang dibutuhkan untuk menjawab tantangan di era industri 4.0 adalah kemampuan berpikir kritis. Kemampuan berpikir kritis yang dimaksud disini adalah berpikir yang baik, logik, terbuka dan mampu beradaptasi dengan 
zaman untuk membuat sebuah terobosan baru demi memajukan bangsa. Pendidikan dalam hal ini diharapkan mampu mempersiapkan peserta didik untuk memilki kemampuan berpikir kritis. Proses pendidikan yang ditempuh peserta didik berperan penting meningkatkan pola berpikir yang baik bagi peserta didik sehingga terbentuk kemampuan berpikir kritisnya. Berpikir kritis sangat penting dimiliki peserta didik di era industri 4.0 ini agar peserta didik mampu memilih, memilah dan menentukan hal-hal yang baik bagi dirinya guna mempersiapkan masa depan yang cemerlang. Menurut Zubaidah (2010) bahwa berpikir kritis dapat diartikan sebagai proses dan kemampuan yang digunakan untuk memahami konsep, menerapkan, mensintesis dan mengevaluasi informasi yang diperoleh atau informasi yang dihasilkan. Tidak semua informasi yang diperoleh dapat dijadikan landasan yang diyakini kebenarannya dalam memutuskan sesuatu, dan tidak selalu informasi yang dihasilkan merupakan informasi yang benar. Dalam hal ini, kemampuan berpikir kritis sangat dibutuhkan untuk memilah informasi yang akan dijadikan rujukan dalam setiap tindakan.

Salah satu model pembelajaran berbasis investigasi adalah model pembelajaran discovey learning. Model pembelajaran ini, memiliki sintaks yang efektif membuat peserta didik aktif dalam proses pembelajaran. Keterlibatan aktif peserta didik terlihat melalui kegiatan praktikum dan kaji literatur yang dilakukan selama proses pembelajran berlangsung. Keaktifan peserta didik dalam memecahkan permasalahan mampu melatihkan kemamupaun berpikir kritisnya sehingga otomatis dapat meningkatkan kemampuan menalar dari peserta didik tersebut. Meningkatnya kemampuan berpikir kritis akan berpengaruh pada hasil belajar peserta didik yang lebih baik. Hal ini sejalan dengan penelitian yang dilakukan Danial, Sawal, \& Nurlaela (2018) bahwa Model Berbasis Investigasi mampu meningkatkan kemampaun berpikir kritis peserta didik salah satunya adalah melalui model pembelajaran discovery learning.

Model pembelajaran discovery learning dikembangkan untuk memotivasi peserta didik dalam belajar sehingga mencapai hasil belajar berupa prestasi akademik, toleransi, menerima keragaman, dan pengembangan keterampilan berpikir kitis. Untuk mencapai hasil belajar itu model pembelajaran discovery learning menuntut kerjasama antara guru dan peserta didik dalam kegiatan pembelajaran. Oleh karena itu, penggunaan model pembelajaran discovery learning dapat meningkatkan motivasi belajar peserta didik yang berpengaruh pada pengembangan kemampuan berpikir kritisnya sehingga mampu meningkatkan hasil belajar peserta didik di kelas. Menurut Balim (2009), model discovery learning membuat peserta didik belajar lebih aktif dengan membangun pengetahuan mereka sendiri. Begitu pula dengan hasil penelitian yang dilakukan oleh Luthfi, Danial, \& Wijaya (2016), menunjukkan bahwa hasil belajar peserta didik yang diberi tugas secara berkelompok dengan model pembelajaran discovery learning lebih tinggi dengan nilai rata-rata 73,80 dibandingkan dengan bekerja secara individu dengan nilai rata-rata hasil belajar 67,71 .

IPA merupakan mata pelajaran yang erat kaitannya dengan gejala-gejala alam disekitar kita. Gejala-gejala tersebut dapat kita ketahui dan pelajari dengan mudah melalui metode berbasis investigasi. Melalui praktikum dan kajian literatur yang dilakukan peserta didik, peserta didik mampu memahami konsep melalui kemampuan berpikir secara logis dan kritis. Berdasarkan hasil observasi melalui wawancara dengan guru IPA di SMP 36 Makassar tentang kegiatan pembelajaran IPA di sekolah tersebut adalah banyak materi yang disajikan dalam model pembelajaran langsung sehingga dan belum pernah dikembangkan perangkat pembelajaran berbasis discovery learning di sekolah tersebut. Kemampaun berpikir ktitis prserta didik masih rendah sehingga hasil 
belajarnya juga rendah. Keterbatasan sarana dan prasarana alat laboratorium dalam menunjang proses pembelajaran peserta didik, membuat kegiatan praktikum peserta didik belum memadai.

Menyikapi permasalahan di atas penulis mengajukan judul penelitian yaitu Pengembangan Perangkat Pembelajaran IPA SMP Berbasis Discovery Learning Berorientasi Meningkatkan Kemampuan Berpikir Kritis dan Hasil Belajar Peserta didik. Dalam mengembangkan perangkat pembelajaran berbasis discovery learning ini menggunakan model pengembangan 4-D oleh Thiagarajan, yang terbagi dalam empat tahap, yaitu pendefinisian (define), perancangan (design), pengembangan (develop), dan penyebaran (dessiminate).

\section{METODE}

Penelitian ini adalah penelitian pengembangan yang meliputi pengembangan atau Research and Development (R\&D) yang bertujuan untuk mengembangkan perangkat pembelajaran berbasis discovery learning yang terdiri dari rencana pelaksanaan pembelajaran (RPP), buku peserta didik, lembar kerja peserta didik (LKPD), dan tes hasil belajar (THB) yang dikembangkan dengan menggunakan model pengembangan 4-D. Uji coba perangkat pembelajaran berbasis discovery learning ini dilaksanakan di SMPN 36 Makassar dengan subjek penelitian adalah kelas VII IPA pada Semester Genap Tahun Pelajaran 2018/2019. Instrumen penelitian yang digunakan adalah lembar validasi LKPD, RPP Buku Peserta Didik dan Tes Hasil Belajar, lembar observasi keterlaksanaan pembelajaran, angket respon guru, lembar pengamatan pengelolaan pembelajaran IPA berbasis discovery learning, lembar pengamatan aktivitas peserta didik, angket respon peserta didik terhadap kegiatan pembelajaran, dan tes hasil belajar. Teknik analisis data pada pengembangan perangkat pembelajaran berbasis discovery learning ini digunakan teknik analisis statistik deskriptif. Data yang dianalisis adalah analisis data kevalidan perangkat pembelajaran, analisis data kepraktisan perangkat pembelajaran, dan analisis data keefektifan perangkat pembelajaran.

\section{HASIL DAN PEMBAHASAN}

\section{Proses Pengembangan Perangkat Pembelajaran IPA Berbasis Discovery Learning}

Proses pengembangan perangkat pembelajaran berbasis discovery learning ini menggunakan model 4D dari Thiagarajan yang terdiri dari empat tahap yaitu define, design, develop, dan disseminate. Tahapan yang dilakukan dimulai dari analisis awal akhir yang bertujuan untuk mengetahui dan menetapkan masalah dasar yang dihadapi dalam proses pembelajaran. Masalah mendasar dari SMP Negeri 36 Makassar yaitu rendahnya kemampuan berpikir kritis peserta didik yang berdampak pada rendahnya hasil belajar. Kegiatan pembelajaran yang masih menggunakan model konvensional yang kurang melibatkan peserta didik dalam kegiatan pembelajaran. Hal ini mengakibatkan peserta didik tidak terbiasa mengkonstruk pengetahuan karena peserta didik hanya mendengar dan mencatat materi yang disampaikan sehingga mengakibatkan rasa bosan dan kurang bersemangat dalam proses pembelajaran.

Pada tahap pendefenisian meliputi lima langkah, yaitu analisis awal-akhir, analisis peserta didik, analisis konsep, analisis tugas, dan perumusan tujuan pembelajaran. Tahap perancangan, pada tahap ini terdapat empat langkah yang ditempuh, yaitu penyusunan tes, pemilihan media, pemilihan format, dan perancangan awal. Tahap pengembangan bertujuan untuk menghasilkan perangkat pembelajaran yang telah direvisi berdasarkan masukan para ahli dan praktisi, serta data yang diperoleh dari hasil uji coba. Kegiatan yang diperoleh pada tahap ini adalah validasi ahli dan praktisi, uji coba di kelas yang menjadi subjek penelitian. Sedangkan pada tahap penyebaran, perangkat pembelajaran IPA berbasis discovery learning pada materi asam basa dan garam diujicobakan pada 
peserta didik kelas VII IPA 1 SMP Negeri 36 Makassar juga disebarkan dan disosialisasikan kepada guru IPA di SMP Negeri 36 Makassar. Hasil sosialisasi tersebut diperoleh beberapa saran dan digunakan untuk memperbaiki perangkat pembelajaran menjadi draft final sebagai pengembangan akhir perangkat pembelajaran.

\section{Kualitas Hasil Pengembangan \\ (Produk)}

Validasi ahli dilakukan untuk melihat validitas perangkat pembelajaran yang dikembangkan dan instrumen yang digunakan dalam uji coba perangkat pembelajaran. Salah satu kriteria utama untuk menentukan apakah sebuah perangkat pembelajaran dapat digunakan atau tidak adalah hasil validasi ahli atau praktisi. Perangkat pembelajaran yang digunakan dalam kegiatan pembelajaran, yaitu rencana pelaksanaan pembelajaran, buku peserta didik, lembar kegiatan peserta didik, dan tes hasil belajar. Penilaian para ahli berupa catatan-catatan kecil pada bagian yang perlu perbaikan. Aspek-aspek yang diperhatikan dalam memvalidasi RPP adalah format RPP, materi (isi) yang disajikan, bahasa, waktu, manfaat/ kegunaan RPP, sarana dan alat bantu pembelajaran. Hasil validasi ahli dapat dilihat pada Tabel 1.

Tabel 1. Rangkuman Hasil Validasi RPP

\begin{tabular}{clcc}
\hline No. & \multicolumn{1}{c}{ Aspek Penilaian } & Penilaian & Kategori \\
\hline 1. & Format RPP & 3,92 & Sangat Valid \\
2. & Materi (isi) yang disajikan & 3,83 & Sangat Valid \\
3. & Bahasa & 4,00 & Sangat Valid \\
4. & Alokasi Waktu & 4,00 & Sangat Valid \\
5. & Manfaat/ Kegunaan RPP & 4,00 & Sangat Valid \\
6. & Sarana dan Alat bantu Pembelajaran & 3,50 & Sangat Valid \\
\hline \multicolumn{2}{r}{ Rata-rata Penilaian Total } & 3,88 & Sangat Valid \\
\hline
\end{tabular}

Berdasarkan tabel 1, menunjukkan bahwa nilai rata-rata kevalidan berada pada kategori sangat valid, yaitu berada pada rentang $3,5 \leq \bar{X} \leq 4,0$ dan berdasarkan perhitungan diperoleh koefisien reliabel $81,25 \%$ atau 0,8125 . Penilaian secara umum oleh para ahli untuk Rencana Pelaksanaan Pembelajaran (RPP) adalah baik dan dapat digunakan dengan sedikit revisi. Dalam penyusunan buku peserta didik, beberapa aspek yang perlu diperhatikan dalam memvalidasi perangkat, yaitu format buku peserta didik, bahasa, isi buku peserta didik, dan manfaat buku peserta didik. Hasil validasi dari ahli dapat dirangkum atau dilihat pada Tabel 2.

Tabel 2. Rangkuman Hasil Validasi Buku Peserta Didik

\begin{tabular}{clcc}
\hline No. & \multicolumn{1}{c}{ Aspek Penilaian } & Penilaian & Kategori \\
\hline 1. & Format Buku Peserta Didik & 3,83 & Sangat Valid \\
2. & Bahasa & 4,00 & Sangat Valid \\
3. & Isi Buku Peserta Didik & 3,83 & Sangat Valid \\
4. & Manfaat Buku Peserta Didik & 4,00 & Sangat Valid \\
\hline \multicolumn{2}{r}{ Rata-rata Penilaian Total } & 3,92 & Sangat Valid \\
\hline
\end{tabular}

Berdasarkan tabel 2, menunjukkan bahwa nilai rata-rata kevalidan berada pada kategori sangat valid, yaitu berada pada rentang $3,5 \leq \bar{X} \leq 4,0$ dan berdasarkan 
perhitungan diperoleh koefisien reliabel $88,89 \%$ atau 0,889 . Penilaian secara umum oleh para ahli untuk buku peserta didik adalah baik dan dapat digunakan dengan sedikit revisi. Dalam menyusun Lembar Kegiatan Peserta Didik (LKPD), beberapa aspek yang perlu diperhatikan dalam memvalidasi perangkat, yaitu format LKPD, bahasa, isi LKPD, waktu, dan manfaat LKPD.

Hasil validasi dari ahli dapat dilihat pada Tabel 3.

Tabel 3. Rangkuman Hasil Validasi LKPD

\begin{tabular}{clcc}
\hline No. & \multicolumn{1}{c}{ Aspek Penilaian } & Penilaian & Kategori \\
\hline 1. & Format LKPD & 4,00 & Sangat Valid \\
2. & Bahasa & 4,00 & Sangat Valid \\
3. & Isi LKPD & 3,75 & Sangat Valid \\
4. & Waktu & 4,00 & Sangat Valid \\
5. & Manfaat LKPD & 4,00 & Sangat Valid \\
\hline \multicolumn{2}{r}{ Rata-rata Penilaian Total } & 3,95 & Sangat Valid \\
\hline & Persentase Kesepahaman & 0,85 & Reliabel \\
\hline
\end{tabular}

Berdasarkan tabel 3, menunjukkan bahwa nilai rata-rata kevalidan berada pada kategori sangat valid, yaitu berada pada 3,5 $\leq \bar{X} \leq 4,0$ dan berdasarkan perhitungan diperoleh koefisien reliabel $85,00 \%$ atau 0,85 artinya persentase of agreementnya $\geq$ 0,75 yang menunjukkan keseluruhan komponen LKPD dinilai reliabel. Penilaian secara umum oleh para ahli untuk LKPD adalah baik dan dapat digunakan dengan sedikit revisi. Dalam menyusun tes hasil belajar (THB), beberapa aspek yang perlu diperhatikan, yaitu materi soal, konstruksi, dan bahasa.

Hasil validasi dari ahli dapat dilihat pada Tabel 4.

Tabel 4. Rangkuman Hasil Validasi Tes Hasil Belajar

\begin{tabular}{clcc}
\hline No. & \multicolumn{1}{c}{ Aspek Penilaian } & Penilaian & Kategori \\
\hline 1. & Materi Soal & 3,90 & Sangat Valid \\
2. & Konstruksi & 4,00 & Sangat Valid \\
3. & Bahasa & 4,00 & Sangat Valid \\
\hline \multicolumn{2}{c}{ Rata-rata Penilaian Total } & 3,97 & Sangat Valid \\
\hline & Persentase Kesepahaman & 0,923 & Reliabel \\
\hline
\end{tabular}

Berdasarkan tabel 4, menunjukkan bahwa nilai rata-rata kevalidan berada pada kategori sangat valid, yaitu berada pada 3,5 $\leq \bar{X} \leq 4,0$ dan berdasarkan perhitungan diperoleh koefisien reliabel $92,31 \%$ atau 0,923 artinya persentase of agreementnya $\geq$ 0,75 yang menunjukkan keseluruhan komponen tes hasil belajar dinilai reliabel. Penilaian secara umum oleh para ahli untuk tes hasil belajar adalah baik dan dapat digunakan dengan sedikit revisi. Dalam tahap proses pengembangan instrumen ini terdapat beberapa instrumen pengumpulan data yang dikembangkan melalui proses validasi.

Adapun rekapitulasi hasil penilaian validator terhadap instrumen penelitian dapat disajikan pada Tabel 5.

Tabel 5. Rekapitulasi Hasil Validasi terhadap Instrumen Penelitian

\begin{tabular}{crccc}
\hline No. & Perangkat Pembelajaran & Rata-rata & Keterangan & Reliabilitas \\
\hline 1. & Lembar Observasi Keterlaksanaan & 3,97 & Sangat Valid & 0,800
\end{tabular}




\begin{tabular}{|c|c|c|c|c|}
\hline & Pembelajaran & & & \\
\hline 2. & $\begin{array}{l}\text { Lembar Observasi Kemampuan Guru } \\
\text { Mengelola Pembelajaran }\end{array}$ & 3,96 & Sangat Valid & 0,867 \\
\hline 3. & Lembar Observasi Aktivitas Peserta Didik & 3,88 & Sangat Valid & 0,889 \\
\hline 4. & $\begin{array}{l}\text { Lembar Angket Respon Guru terhadap } \\
\text { Pembelajaran }\end{array}$ & 3,86 & Sangat Valid & 0,750 \\
\hline 5. & $\begin{array}{l}\text { Lembar Angket Respon Peserta Didik } \\
\text { terhadap Pembelajaran }\end{array}$ & 3,92 & Sangat Valid & 0,875 \\
\hline
\end{tabular}

Pada tabel 5, menunjukkan bahwa (1) keseluruhan komponen lembar observasi keterlaksanaan pembelajaran, lembar observasi kemampuan guru mengelola pembelajaran, lembar aktivitas peserta didik, lembar angket respon guru, dan lembar angket respon peserta didik dinilai sangat valid yaitu berada pada $3,5 \leq \bar{X} \leq 4,0$. (2) Keseluruhan komponen instrumen penelitian reliabel dengan koefisien reliabilitas rata-rata $\geq 0,75$. (3) Penilaian secara umum oleh para ahli untuk instrumen penelitian ini adalah baik dengan sedikit revisi.

Salah satu kriteria utama untuk menilai suatu perangkat pembelajaran praktis atau tidak untuk digunakan adalah berdasarkan hasil analisis penilain oleh pengamat. Analisis kepraktisan perangkat pembelajaran diperoleh dari hasil analisis pengamatan keterlaksanaan perangkat pembelajaran. Tujuan utama analisis data keterlaksanaan perangkat pembelajaran adalah untuk melihat sejauh mana tingkat keterlaksanaan perangkat dalam proses pembelajaran. Dalam mengobservasi keterlaksanaan perangkat, peneliti menggunakan dua orang guru mitra sebagai pengamat pada setiap pertemuan. Hasil analisis terhadap pengamatan keterlaksanaan perangkat pembelajaran dilakukan dengan menghitung rata-rata penilaian kemudian mengkonversi ke dalam kategori, selain itu menghitung reliabilitas instrumen agar data hasil uji coba layak dipergunakan untuk menilai kepraktisan perangkat pembelajaran. Berdasarkan hasil analisis data observasi pengamatan tentang keterlaksanaan pembelajaran dari 4 kali pertemuan dapat dirangkum pada Tabel 6.

Tabel 6. Hasil Analisis Pengamatan Keterlaksanaan Perangkat Pembelajaran

\begin{tabular}{clccc}
\hline No. & \multicolumn{1}{c}{ Aspek } & Rata-rata & Keterangan & Reliabilitas \\
\hline 1. & Sintaks & 1,86 & Terlaksana Seluruhnya & 0,75 \\
2. & Interaksi Sosial & 1,72 & Terlaksana Seluruhnya & 0,69 \\
3. & Prinsip Reaksi & 1,75 & Terlaksana Seluruhnya & 0,83 \\
4. & Sistem Pendukung & 1,80 & Terlaksana Seluruhnya & 0,80 \\
\hline \multicolumn{2}{r}{ Rata-rata total $(\overline{\mathrm{X}})$} & 1,80 & Terlaksana Seluruhnya & 0,77 \\
\hline
\end{tabular}

bahwa keterlaksanaan perangkat pembelajaran adalah berada pada nilai ratarata $\bar{X}=1,80$, yang berarti aspek dan kriteria yang diamati pada keterlaksanaan perangkat pembelajaran pada umumnya terlaksana seluruhnya yaitu berada pada $1,5 \leq \mathrm{M} \geq 2,0$, dan berdasarkan perhitungan didapatkan koefisien reliabilitas $77 \%$ atau 0,77 menunjukkan keterlaksanaan perangkat pembelajaran dinilai reliabel. Dengan demikian dapat disimpulkan bahwa keterlaksanaan perangkat pembelajaran IPA berbasis discovery learning yang telah diujicoba telah memenuhi kriteria praktis.

Hasil analisis respon guru terhadap perangkat pembelajaran IPA berbasis discovery learning. Tujuan utama analisis data respon guru terhadap proses pembelajaran adalah untuk melihat bagaimana respon guru terhadap perangkat pembelajaran IPA berbasis discovery 
learning. Hasil analisis tersebut dapat dilihat pada Tabel 7.

Tabel 7. Hasil Respon Guru terhadap Pembelajaran IPA

\begin{tabular}{cccc}
\hline No. & \multicolumn{1}{c}{ Aspek } & $\begin{array}{c}\text { Rata-rata } \\
\text { Persentase }\end{array}$ & Keterangan \\
\hline 1. & Penilaian terhadap perangkat pembelajaran berupa RPP & 91,25 & Sangat Positif \\
2. & Penilaian terhadap perangkat pembelajaran berupa BPD & 87,50 & Sangat Positif \\
3. Penilaian terhadap perangkat pembelajaran berupa LKPD & 92,50 & Sangat Positif \\
4. Penilaian terhadap perangkat pembelajaran berupa THB & 94,64 & Sangat Positif \\
5. Penilaian terhadap proses pembelajaran & 90,91 & Sangat Positif \\
\hline & Rata-rata total $(\overline{\mathrm{X}})$ & 91,36 & Sangat Positif \\
\hline
\end{tabular}

Tabel 7, terlihat bahwa persentase rata-rata respon guru terhadap pembelajaran yang menggunakan perangkat pembelajaran IPA berbasis discovery learning sebesar 91,36\%. Secara keseluruhan berada dalam kategori sangat positif yaitu berada pada rentang $81 \%-100 \%$.

Analisis hasil pengamatan kemampuan guru mengelola pembelajaran dengan tujuan utama dalam mengelola pembelajaran adalah untuk melihat kemampuan guru dalam mengelola pembelajaran. Data pengelolaan pembelajaran diperoleh melalui observasi yang dilakukan oleh dua guru mitra sebagai pengamat setiap pertemuan. Berdasarkan hasil analisis data observasi pengamat tentang pengelolaan pembelajaran selama 4 kali pertemuan terlihat bahwa rata-rata kemampuan guru dalam mengelola pembelajaran sebesar 3,63 dan berada pada kategori sangat tinggi dengan rentang 3,5 $\leq$ $\mathrm{KG} \leq 4$ dan berdasarkan perhitungan didapatkan koefisien reliabilitas $81 \%$ atau 0,81 artinya persentase kesepahaman $\geq 0,75$ yang menunjukkan kemampuan guru dalam mengelola pembelajaran dinilai reliabel.

Instrumen lembar pengamatan aktivitas peserta didik digunakan untuk mengamati aktivitas peserta didik selama kegiatan pembelajaran berlangsung. Pengamatan dilakukan oleh dua orang pengamat, setiap pengamat mengamati 2 kelompok peserta didik yang terpilih. Pengamat mengambil posisi terdekat dengan kelompok yang diamati. Hasil analisis aktivitas peserta didik dapat dikemukakan bahwa semua aspek aktivitas peserta didik yang diamati memeliki frekuensi dan persentase yang tinggi, ini berarti aktivitas peserta didik sesuai yang diharapkan berada dalam kategori sangat baik. Persentase yang didapatkan dari pertemuan pertama sampai pertemuan keempat adalah rata-rata 93,28\%. Sedangkan instrumen yang digunakan untuk memperoleh data respon peserta didik adalah angket respon peserta didik. Angket ini diberikan kepada peserta didik setelah mengikuti kegiatan pembelajaran dengan menggunakan perangkat pembelajaran berbasis discovery learning. Hasil analisis data respon peserta didik terhadap perangkat pembelajaran diisi oleh 24 peserta didik dan persentase rata-rata respon peserta didik terhadap pembelajaran yang menggunakan perangkat pembelajaran IPA berbasis discovery learning sebesar $89,90 \%$. Secara keseluruhan berada dalam kategori sangat positif yaitu berada pada rentang $81 \%$ $100 \%$.

$\begin{array}{rrr}\text { Perangkat } & \text { pembelajaran } & \text { dikatakan } \\ \text { efektif apabila } & \text { memenuhi } & \text { kriteria }\end{array}$ keefektifan. Kriteria-kriteria tersebut, yaitu ketercapaian hasil belajar peserta didik yaitu $80 \%$ (skor minimal 75 untuk rentang skor 0 - 100). Tes yang digunakan pada penelitian ini adalah tes uraian sebanyak 8 nomor. Analisis tes digunakan untuk mengetahui tingkat pencapaian hasil belajar. Gambaran hasil analisis deskriptif nilai tes hasil belajar peserta didik setelah mengikuti pembelajaran menggunkan perangkat pembelajaran berbasis discovery learning dapat dilihat pada Tabel 8. 
Tabel 8. Statistik Nilai Hasil Belajar Peserta Didik

\begin{tabular}{lcc}
\hline \multirow{2}{*}{ Variabel } & \multicolumn{2}{c}{ Nilai Statistik } \\
\cline { 2 - 3 } & Pre-test & Post-test \\
\hline Subjek Penelitian & 24 & 24 \\
Nilai Ideal & 100 & 100 \\
\hline Nilai Maksimum & 21,15 & 100 \\
Nilai Minimum & 0 & 57,69 \\
Rata-rata & 7,85 & 82,09 \\
Rentang & 7,85 & 42,31 \\
Standar Deviasi & 3,85 & 9,61 \\
Jumlah peserta didik yang tuntas & - & 28 \\
Jumlah peserta didik yang tidak tuntas & 24 & 4 \\
\hline
\end{tabular}

Tabel 8, menunjukkan bahwa nilai rata-rata hasil belajar peserta didik kelas VII IPA 1 SMP Negeri 36 Makassar sebelum dilakukan pembelajaran IPA berbasis discovery learning pada materi asam basa dan garam adalah rata-rata 7,85 dengan skor ideal 100. Nilai tertinggi sebesar 21,15 dan nilai terendah 0 . Sedangkan hasil tes hasil belajar peserta didik setelah melalui pembelajaran discovery learning adalah rata-rata 82,09 dengan skor ideal 100 , nilai tertinggi 100 dan nilai terendah 57,69 dengan rentang nilai 42,31. Berdasarkan analisis statistik keterampilan berpikir kritis peserta didik dengan menggunakan SPSS 16 diperoleh hasil bahwa keterampilan berpikir kritis dalam kategori tinggi pada pos-test sebanyak 19 orang dengan persentasi $54,28 \%$, kategori sedang sebanyak 12 orang dengan presentasi $42,86 \%$ dan kategori rendah sebanyak 1 orang dengan persentasi $2,86 \%$. Adapun hasil keterampilan berpikir kritis untuk pre-test, jumlah peserta didik dengan kategori tinggi dan sedang tidak ada, sedangkan kategori rendah sebanyak 32 orang dengan persentase $100 \%$.

$$
\text { Rata-rata penilaian penilaian }
$$
validator terhadap RPP dari aspek format, materi yang disajikan, bahasa, alokasi waktu, manfaat, sarana dan alat bantu pembelajaran adalah 3,88 dengan kategori sangat valid karena berada pada rentang 3,5 $\leq \mathrm{M} \leq 4$ dengan persentase kesepahaman 0,81 . Hal ini berarti bahwa RPP di susun sesuai dengan prinsip-prinsip pengembangan RPP, dan seluruh komponen dalam penyusunan RPP telah tercantum, sehingga RPP ini dapat diterapkan dalam kegiatan pembelajaran. Meskipun demikian, ada beberapa aspek yang perlu diperhatikan agar dapat menghasilkan RPP yang lebih baik, yakni ketepatan penjabaran kompetensi dasar ke indikator pencapaian kompetensi, pengembangan indikator menjadi tujuan pembelajaran, dan kesesuaian tujuan pembelajaran dengan tingkat perkembangan kognitif peserta didik. Aspek lain yang perlu diperhatikan adalah kesesuaian antara alokasi waktu yang digunakan dengan tahapan pembelajaran dengan model discovery lerning. Oleh karena itu dilakukan revisi berdasarkan saran dari kedua validator. Saran-saran tersebut meliputi (1) menuliskan contoh manfaat dalam kehidupan sehari-hari, ketika mempelajari asam, basa dan garam untuk memotivasi peserta didik, (2) dalam merumuskan soal dalam penilaian harus mencantumkan indikator pencapain kompetensi, menuliskan rumus untuk memperoleh penilaian sikap. Hasil akhir revisi perangkat tersebut merupakan perangkat draft kedua (Prototipe II) yang digunakan pada uji coba perangkat.

Hasil uji kelayakan terhadap perangkat pembelajaran juga dilakukan oleh Khomsiatun \& Retnawati (2015), hasil validasi RPP menunjukkan total skor adalah 495 sehingga RPP termasuk dalam kategori "valid" sehingga RPP yang dihasilkan layak digunakan setelah dilakukan perbaikanperbaikan sesuai saran. Hasil penelitian lain 
yang dilakukan oleh Hutami \& Wiyatmo (2018), diperoleh hasil validasi terhadap perangkat pembelajaran fisika berbasis guided discovery learning berupa RPP termasuk dalam kategori sangat baik dengan skor rata-rata 4,60 .

Hasil analisis terhadap buku peserta didik memperlihatkan bahwa rata-rata penilaian terhadap buku peserta didik ditinjau dari aspek format, bahasa yang digunakan, materi atau isi buku, dan manfaat atau kegunaan buku dalam pembelajaran adalah 3,92 dengan kategori sangat valid karena pada rentang 3,5 $\leq \mathrm{M} \leq 4$ dengan persentase kesepahaman 0,889 atau $88,89 \%$. Hal ini berarti bahwa buku peserta didik telah disusun berdasarkan pada rasional teoritik yang kuat dan memiliki konsistensi internal, yakni saling berkaitan antar komponen dalam buku tersebut dengan perangkat lain, sehingga buku ini dapat digunakan sebagai bahan ajar dalam kegiatan pembelajaran. Namun demikian berdasarkan saran dan komentar validator maka dilakukan revisi kecil untuk penyempurnaan perangkat buku peserta didik. Hasil akhir revisi buku peserta didik tersebut merupakan perangkat draft kedua (Prototipe II) yang digunakan pada uji coba perangkat.

Hasil penelitian ini sejalan dengan hasil penelitian yang dilakukan oleh Rahmawati, Mardiana, \& Subanti (2014), diperoleh hasil validasi buku siswa yaitu semua komponen penilaian berada dalam kategori sangat baik, sehingga perangkat layak digunakan. Penilaian umum dari ketiga validator adalah buku siswa dapat digunakan dengan sedikit revisi. Sementara hasil penelitian Permana \& Pujiastuti (2017), menunjukkan bahwa hasil validasi pengembangan buku ajar pada pembelajaran tematik integratif berbasis discovery learning subtema sumber energi kelas III memperoleh skor 166 dengan kategori baik, sehingga buku ajar layak untuk digunakan.

$\begin{array}{llll}\text { Hasil analisis terhadap lembar } & \text { lempor } \\ \text { kegiatan peserta } & \text { didik } & \text { (LKPD) }\end{array}$ memperlihatkan bahwa rata-rata penilaian terhadap LKPD ditinjau dari aspek format, bahasa yang digunakan, materi atau isi LKPD, waktu, dan manfaat atau kegunan LKPD dalam pembelajaran adalah 3,95 dengan kategori sangat valid karena pada rentang $3,5 \leq \mathrm{M} \leq 4$ dengan persentase kesepahaman 0,85 atau $85,00 \%$. Hal ini berarti bahwa LKPD telah disusun berdasarkan pada rasional teoritik yang kuat dan memiliki konsistensi internal, yakni saling berkaitan antar komponen dalam LKPD tersebut dengan perangkat lain, sehingga LKPD ini dapat digunakan dalam kegiatan pembelajaran. Namun demikian berdasarkan saran dan komentar validator maka dilakukan revisi kecil untuk penyempurnaan perangkat lembar kegiatan peserta didik (LKPD). Beberapa aspek yang perlu diperhatikan agar dapat menghasilkan LKPD yang baik, yakni kejelasan rumusan tujuan pembelajaran, kejelasan pembagian materi asam, basa, dan garam, bahasa yang digunakan dapat mendorong minat peserta didik untuk bekerja, dan kalimat soal tidak mengandung arti ganda. Hasil penelitian lainnya tentang uji kelayakan terhadap LKPD digital dengan metode guided discovery learning berbantuan e-learning dilakukan oleh Marzuki, Slamin, \& Dafik (2014), hasil validasi terhadap LKPD diperoleh skor 0,919 dengan kategori sangat valid.

Hasil analisis terhadap tes hasil belajar (THB) memperlihatkan bahwa ratarata penilaian terhadap THB ditinjau dari aspek materi soal, konstruksi, dan bahasa yang digunakan adalah 3,97 dengan kategori sangat valid karena berada pada rentang 3,5 $\leq \mathrm{M} \leq 4$ dengan persentase kesepahaman 0,923 atau 92,30\%. Namun demikian, tes hasil belajar yang disusun tetap direvisi sedikit dengan memperhatikan soal harus sesuai dengan indikator pencapaian kompetensi. Tes hasil belajar yang telah direvisi diujicobakan sebelum pembelajaran IPA berbasis discovery learning pada materi asam, basa, dan garam untuk mengetahui kemampuan awal peserta didik dan setelah akhir proses pembelajaran IPA berbasis discovery learning pada materi asam, basa, dan garam untuk mengukur 
kemampuan, dan peningkatan hasil belajar peserta didik setelah mengikuti kegiatan pembelajaran.

Hasil analisis terhadap tes kemampuan berpikir kritis (TKBK) memperlihatkan bahwa rata-rata penilaian terhadap TKBK ditinjau dari aspek materi soal, konstruksi, dan bahasa yang digunakam adalah 3,97 dengan kategori sangat valid karena berada pada rentang 3,5 $\leq \mathrm{M} \leq 4$ dengan persentase kesepahaman 0,923 atau $92,30 \%$. Namun demikian, tes kemampuan berpikir kritis yang disusun tetap direvisi sedikit dengan memperhatikan soal harus sesuai dengan indikator aspek berpikir kritis. Tes kemampuan berpikir kritis yang telah direvisi diujicobakan sebelum pembelajaran IPA berbasis discovery learning pada materi asam, basa, dan garam untuk mengetahui kemampuan awal peserta didik dan setelah akhir proses pembelajaran IPA berbasis discovery learning pada materi asam, basa, dan garam untuk mengukur kemampuan, dan peningkatan hasil belajar peserta didik setelah mengikuti kegiatan pembelajaran.

Secara umum semua penilaian validator terhadap perangkat pembelajaran yang dikembangkan baik RPP, Buku Peserta Didik (BPD), Lembar Kegiatan Peserta Didik (LKPD), dan Tes Hasil Bealajar (THB) berada pada kategori sangat valid dan memberikan kesimpulan baik dan dapat digunakan dengan sedikit revisi, hal ini berarti bahwa seluruh perangkat pembelajaran yang divalidasi telah layak untuk diuji cobakan. Dalam melakukan revisi peneliti mengacu pada saran-saran serta petunjuk validator.

Secara umum, hasil penilaian ahli dan praktisi terhadap perangkat pembelajaran IPA berbasis discovery learning menyatakan bahwa perangkat layak digunakan dalam pembelajaran. Berdasarkan hasil penilaian pengamat dan hasil analisis persentase kesepahaman dapat disimpulkan bahwa keterlaksanaan perangkat pembelajaran IPA berbasis discovery learning yang telah diujicoba telah memenuhi kriteria praktis. Hasil uji kepraktisan berdasarkan hasil pengamatan keterlaksanaan pembelajaran juga dilakukan oleh Hasriani (2017), diperoleh bahwa perangkat pembelajaran praktis berdasarkan hasil keterlaksanaan perangkat pembelajaran dengan nilai rata-rata 1,88 berada pada kategori terlaksana seluruhnya. Hasil penelitian lain juga dilakukan oleh Suryani (2016), berdasarkan hasil penelitian bahwa keterlaksanaan proses pembelajaran dengan model discovery learning dari sisi pengguna (dosen) menunjukkan bahwa terlaksana $87,88 \%$ terlaksana dengan sangat baik sedangkan dari sisi mahasiswa yakni $83,33 \%$ juga terlaksana dengan baik.

Respon guru terhadap perangkat pembelajaran diketahui dengan memberikan angket kepada guru untuk mengetahui pendapat guru mengenai perangkat pembelajaran yang dikembangkan. Dari respon ini dapat diketahui kepraktisan perangkat pembelajaran karena angket ini memuat pernyataan-pernyataan mengenai perangkat pembelajaran berupa RPP, BPD, LKPD, THB, dan proses pembelajaran. Rata-rata respon guru sebesar 91,36\% yaitu berada pada kategori sangat positif. Hal ini berarti bahwa perangkat pembelajaran yang telah dikembangkan praktis dan dapat digunakan dalam pembelajaran IPA berbasis discovery learning. Hasil uji kepraktisan berdasarkan respon guru terhadap perangkat pembelajaran juga dilakukan oleh Sugiarti \& Mariantha (2017), diperoleh rata-rata respon guru terhadap perangkat sebesar 87,77 dengan kategori baik. Hal ini menunjukkan bahwa perangkat pembelajaran yang dikembangkan mudah digunakan dalam kegiatan pembelajaran.

Secara umum hasil analisis data aktivitas peserta didik menunjukkan bahwa aktivitas ke-1, ke-2, ke-3, ke-4, ke-5, ke-6, ke-7, dan ke-8 pada setiap pertemuan yang diamati memiliki frekuensi dan persentase yang tinggi. Ini berarti aktivitas peserta didik sesuai yang diharapkan karena berada pada kategori sangat baik, karena persentase yang didapatkan dari pertemuan pertama sampai pertemuan kelima rata-rata persentasenya mencapai 93,28\%. Artinya pembelajaran 
IPA pada materi asam, basa, dan garam dengan menggunakan perangkat pembelajaran berbasis discovery learning membuat peserta didik semakin aktif dalam kegiatan pembelajaran. Hasil analisis aktivitas peserta didik menunjukkan ratarata keseluruhan aktivitas peserta didik berada dalam kategori sangat baik, kecuali untuk aktivitas meminta bimbingan kepada guru jika mengalami kesulitan di dalam kelompok dengan rata-rata persentase $75 \%$ dengan kategori baik. Hal ini disebabkan karena pengamatan aktivitas hanya terbatas pada dua kelompok, selain itu waktu yang digunakan untuk setiap langkah dalam kegiatan pembelajaran telah ditentukan sehingga tidak memungkinkan semua peserta didik bertanya jika mengalami kesulitan.

Dari hasil analisis pengamatan kemampuan guru mengelola pembelajaran dengan aspek yang diamati yaitu kegiatan awal, kegiatan inti, kegiatan akhir, dan pengamatan suasana kelas. Rata-rata total aspek yang diamati berada dalam kategori sangat tinggi. Namun pada setiap bagian aspek terdapat pengamatan dengan kategori tinggi. Untuk kegiatan pendahuluan guru diharapkan memberikan motivasi yang lebih kepada peserta didik tentang pentingnya materi yang akan dipelajari. Untuk kegiatan inti guru lebih mengarahkan peserta didik dalam menemukan informasi penting untuk mengolah data, hal ini disebabkan karena peserta didik masih terkendala dalam mengolah data, peserta didik sulit mengolah data yang diperoleh untuk menyelesaikan masalah. Pada Kegiatan penutup terkendala pada saat refleksi/ evaluasi, peserta didik memerlukan waktu yang lebih untuk menyelesaikan soal yang diberikan.

Respon peserta didik terhadap pelaksanaan pembelajaran berdasarkan angket yang diberikan diperoleh persentase sebesar 89,41\%, respon peserta didik terhadap buku peserta didik sebesar $90,25 \%$ dan respon terhadap LKPD sebesar 90,05\%. Dari keseluruhan aspek yang diamati ratarata respon positif yang diberikan oleh peserta didik adalah $89,90 \%$. Hal ini menunujukkan bahwa rata-rata peserta didik setuju terhadap pelaksanaan pembelajaran berbasis discovery learning, dan seluruh aspek yang ditanyakan dalam pelaksanaan kegiatan pembelajaran dengan menggunakan perangkat pembelajaran IPA berbasis discovery learning didapatkan respon positif yang sangat tinggi atau sangat positif. Dari persentase tersebut menunjukan bahwa kriteria perangkat pembelajaran dikatakan praktis jika respon peserta didik minimal berada pada kategori positif, sehingga perangkat pembelajaran praktis digunkan dalam kegiatan pembelajaran.

Hasil uji kepraktisan berdasarkan hasil respon peserta didik terhadap perangkat dan proses pembelajaran juga dilakukan oleh Rahmadani (2015) diperoleh bahwa perangkat pembelajaran praktis berdasarkan hasil respon peserta didik dengan nilai rata-rata $80 \%$ berada pada kategori sangat positif. Sementara dalam penelitian Indiastuti (2016), diperoleh hasil rekap respon peserta didik menunjukkan rata-rata $84,5 \%$ dengan kriteria baik, maka respon peserta didik tersebut positif.

Tes hasil belajar diberikan kepada peserta didik untuk memperoleh informasi tentang penguasaan peserta didik terhadap materi yang telah diajarkan. Hasil belajar peserta didik kelas VII IPA SMP Negeri 36 Makassar terhadap pembelajaran IPA berbasis discovery learning pada materi asam, basa, dan garam diperoleh skor ratarata 84,07 dari skor maksimal 100. Skor terendah 57,69 dan skor tertinggi 100 dengan rentang skor 42,31. Berdasarkan hasil analisis, menunjukkan bahwa persentase hasil belajar peserta didik sebesar $12,50 \%$ berada pada kategori sangat baik, $25,00 \%$ pada kategori baik, $50 \%$ berada pada kategori cukup, dan $14,67 \%$ pada kategori kurang.

Pada dasarnya penelitian seperti ini telah pernah dilakukan oleh peneliti sebelumnya Azzahro (2014). Dari hasil penelitian diperoleh data menunjukkan bahwa secara klasikal, peserta didik memperoleh pemahaman yang baik terhadap materi yang disajikan dengan menggunakan 
perangkat pembelajaran IPA berbasis discovery learning. Penelitian yang dilakukan oleh Luthfi, Danial, \& Wijaya (2016) dengan demikian, perangkat pembelajaran IPA berbasis discovery learning efektif digunakan pada pembelajaran asam, basa, dan garam. Hasil yang diperoleh pada umumnya sama dengan hasil yang diperoleh pada penelitian pengembangan perangkat pembelajaran yang dilakukan oleh peneliti saat ini. Hasil yang diperoleh menyatakan bahwa pembelajaran berbasis discovery learning dapat meningkatkan hasil belajar peserta didik, terbukti $85,33 \%$ peserta didik tuntas dalam pembelajaran, dimana nilai rata-rata yang diperoleh peserta didik berada pada kategori baik.

Berdasarkan deskripsi data keterampilan berpikir kritis peserta didik menunjukkan gambaran umum keterampilan berpikir kritis peserta didik baik pada sebelum dan sesudah pembelajaran. Nilai tertinggi sesudah diberi pembelajaran lebih besar dari pada sebelum diberi pembelajaran yaitu 100 untuk sesudah pembelajaran dan 52 untuk sebelum pembelajaran. Selain nilai tertinggi, nilai rata-rata sesudah pembelajaran juga lebih besar, yaitu 85,17 , sedangkan sebelum pembelajaran sebesar 28,77. Hasil tersebut menunjukkan bahwa nilai rata-rata peserta didik sesudah pembelajaran lebih tinggi dari pada sebelum pembelajaran dengan selisih 56,40 poin. Lebih besarnya nilai sesudah pembelajaran menunjukkan bahwa keterampilan berpikir kritis peserta didik sesudah pembelajaran lebih baik dari pada sebelum pembelajaran.

Hasil posttest dan pretest yang mewakili 5 indikator keterampilan berpikir kritis yang terdiri dari beberapa sub indikator yang ada di dalamnya, pada hasil post-test diperoleh rata-rata keterampilan berpikir kritisnya lebih tinggi daripada pretest. Indikator berpikir kritis yang pertama yaitu memberikan penjelasan sederhana, persentasi yang diperoleh dari posttest sebesar $98,57 \%$ sedangkan pada pretest sebesar $53,71 \%$. Indikator berpikir kritis yang kedua yaitu membangun keterampilan dasar, persentasi yang diperoleh pada posttest sebesar 98,90\% sedangkan pada pretest sebesar $42,01 \%$. Indikator berpikir kritis yang ketiga yaitu memberikan penjelasan lebih lanjut, persentasi yang diperoleh dari posttest sebesar $83,68 \%$ sedangkan pada pretest sebesar $21,97 \%$. Indikator berpikir kritis yang keempat yaitu mengatur strategi dan taktik, persentasi yang diperoleh pada posttest sebesar $83,21 \%$ sedangkan pada pretest sebesar $29,13 \%$. Indikator berpikir kritis yang kelima yaitu menyimpulkan, persentasi yang diperoleh pada posttest sebesar $65,41 \%$ sedangkan pada pretest sebesar $8,60 \%$. Pada indikator berpikir kritis yang kelima ini pada posttest yang diperoleh nilai persentasi tergolong sedang karena kebanyakan peserta didik tidak menjawab semua soalnya dan kalaupun menjawab semua namun hasil perhitungannya salah, sehingga pada saat menyimpulkan menjadi salah pula. Pada instrument penelitian terdiri dari sebagian besar soal perhitungan dimana pembelajaran yang dilaksanakan lebih mengarah kepada konsep-konsep. Pembelajaran dengan konsep-konsep tersebut menyebabkan kurangnya contohcontoh utamanya pada soal perhitungan sehingga mempengaruhi kemampuan berpikir kritis peserta didik, serta sebelum menyimpulkan suatu permasalahan atau soal harus mengatur strategi dan taktik yang baik dan benar-benar matang agar menghasilkan kesimpulan yang baik dan benar. Tapi secara keseluruhan diperoleh keterampilan berpikir kritis peserta didik mengalami peningkatan yang terlihat dari persentase rata-rata tiap aspek keterampilan berpikir kritis mengalami kenaikan.

Hasil uji peningkatan keterampilan berpikir kritis yang dilakukan oleh Rahma (2012) diperoleh hasil uji N-gain keterampilan berpikir kritis dari pengembangan perangkat pembelajaran model inkuiri berpendekatan SETS dengan menggunakan model pengembangan 3-D termasuk dalam kategori tinggi dengan nilai $\mathrm{N}$-gain sebesar 0,72 . 
Hasil uji peningkatan keterampilan berpikir kritis yang dilakukan juga oleh Wahyuni (2015) diperoleh hasil keterampilan berpikir kritis dari pengembangan bahan ajar dengan menggunakan model pengembangan 4-D menunjukkan peningkatan KBK baik yang diambil dengan teknik tes maupun praktikum. Berdasarkan dari teknik tes diperoleh hasil $75 \%$ peserta didik memiliki kemampuan berpikir kritis dan $7,5 \%$ memiliki kemampuan sangat kritis. Kemudian hasil uji keefektifan yang dilakukan oleh Khotim, Nurhayati, \& Hadisaputro (2015) diperoleh hasil uji Ngain hasil belajar peserta didik dari pengembangan modul berbasis masalah dengan menggunakan model 3-D termasuk dalam kategori sedang dengan nilai $\mathrm{N}$-gain sebesar 0,41 . Hasil penelitian lainnya yang berhubungan dengan uji keefektifan yang dilakukan oleh Alfana, Dewi, \& Sukaesih (2015) diperoleh hasil uji N-Gain hasil belajar dan kemampuan berpikir kreatif peserta didik dari pengembangan LKS berbasis konstruktivisme dengan menggunakan model pengembangan 4-D termasuk dalam kategori sedang dengan nilai $\mathrm{N}$-gain sebesar 0,52 .

\section{SIMPULAN DAN SARAN}

Berdasarkan hasil penelitian dan pembahasan, maka dapat disimpulkan bahwa pengembangan perangkat pembelajaran pada penelitian ini menggunakan model 4-D. Perangkat pembelajaran dalam penelitian ini valid, praktis, dan efektif. Berdasarkan hasil yang diperoleh dari penelitian ini, dapat dikemukakan beberapa saran yaitu perangkat pembelajaran yang dikembangkan dalam penelitian ini sudah memenuhi kriteria kualitas baik sehingga dapat diimplementasikan oleh guru-guru dalam pembelajaran di kelas untuk materi asam basa, dan garam, sehinga dihasilkan perangkat pembelajaran yang lebih baik, karena perangkat pembelajaran yang dihasilkan hanya melalui satu kali uji coba. Pengembangan perangkat pembelajaran IPA berbasis discovery learning hendaknya dikembangkan untuk materi lain yang cocok diajarkan dengan model ini, sehingga peserta didik akan lebih termotivasi dan dapat mengkonstruksi sendiri pengetahuannya. Bagi peneliti yang berminat mengembangkan lebih lanjut penelitian ini, diharapkan untuk melihat bagaimana kondisi peserta didik dan menggunakan observer yang disesuaikan dengan banyaknya komponen yang diamati.

\section{DAFTAR RUJUKAN}

Alfana, M., Dewi, N. R., \& Sukaesih, S. 2015. Pengembangan Lembar Kerja Siswa IPA Terpadu Berbasis Konstruktivisme Tema Energi dalam Kehidupan untuk Siswa SMP. Unnes Science Education Journal, 4(1), 720-727.

Azzahro, I. F. 2014. Pengembangan Perangkat Pembelajaran Berbasis Discovery Learning pada Sub Materi Respirasi dan Fotosintesis Kelas VII SMP. Pensa E-Jurnal: Pendidikan Sains, 2(3), 1-9.

Balim, A. G. 2009. The Effects of Discovery Learning on Students' Success and Inquiry Learning Skills. Eurasian Journal of Educational Research, 35, 1-20.

Danial, M., Sawal, M., \& Nurlaela. 2018. Development of Chemistry Instructional Tools and Its Effect on Critical Thinking Skills, Metacognition, and Concept Mastery of Students. Journal of Physics Conference Series, 1028(1), 1-8.

Hasriani. 2017. Pengembangan Perangkat Pembelajaran Matematika Berbasis Penemuan Terbimbing (Discovery Learning) pada Pokok Bahasan Bangun Datar (Segiempat dan Segitiga) Kelas VII SMP Negeri 1 Sungguminasa Kab. Gowa. Skripsi. Makassar: Universitas Islam Negeri Alauddin Makassar.

Hilda, L. 2017. Higher Order Thingking Skill dalam Menghadapi Era Revolusi Industri 4.0. 
Padangsidimpuan: $\quad$ Fakultas Tarbiyah dan Ilmu Keguruan IAIN Padangsidimpuan.

Hutami, D. P., \& Wiyatmo, Y. 2018. Pengembangan Perangkat Pembelajaran Berbasis Guided Discovery Learning untuk Meningkatkan Pemahaman Konsep dan Kemampuan Kerjasama Peserta Didik. E-Jurnal Pendidikan Fisika, 7(1), 18-28.

Indiastuti, F. 2016. Pengembangan Perangkat Model Discovery Learning Berpendekatan Saintifik untuk Meningkatkan Berpikir Kreatif dan Rasa Ingin tahu. Jurnal Pendidikan Matematika JPM RAFA, 2(1), 41-55.

Khomsiatun, S., \& Retnawati, H. 2015. Pengembangan Perangkat Pembelajaran dengan Penemuan Terbimbing untuk Meningkatkan Kemampuan Pemecahan Masalah. Jurnal Riset Pendidikan Matematika, 2(1), 92-106.

Khotim, H. N., Nurhayati, S., \& Hadisaputro, S. 2015. Pengembangan Modul Kimia Berbasis Masalah pada Materi Asam Basa. Chemistry in Education, 4(2), 63-69.

Luthfi, A. I., Danial, M., \& Wijaya, M. 2016. Perbandingan Metode Pemberian Tugas Kerja Kelompok dan Kerja Individu pada Model Pembelajaran Discovery Learning terhadap Hasil Belajar Peserta Didik Kelas XI MIA SMAN 1 Tondong Tallasa Kab. Pangkep (Studi pada Materi Pokok Termokimia). Jurnal Chemica, 17(1), 58-66.

Marzuki, L., Slamin, \& Dafik. 2014. Pengembangan Perangkat Pembelajaran Metode Guided Discovery Learning Berbantuan ELearning dengan Aplikasi Atutor pada Pokok Bahasan Lingkaran Kelas VIII SMP. Jurnal Unej Pancaran, 3(2), 25-34.

Permana, A. B., \& Pujiastuti, P. 2017. Pengembangan Buku Ajar Tematik Integratif Berbasis Discovery
Learning dalam Peningkatan Motivasi Belajar dan Karakter Tanggung Jawab. Jurnal Pendidikan Karakter, 7(1), 46-55.

Purwanto, B., \& Nugroho, A. 2018. Eksplorasi Ilmu Alam I untuk Kelas VII SMP dan MTs. Kurikulum 2013. Solo: PT Tiga Serangkai Pustaka Mandiri.

Rahma, A. N. 2012. Pengembangan Perangkat Pembelajaran Model Inkuiri Berpendekatan SETS Materi Kelarutan dan Hasil Kali Kelarutan untuk Menumbuhkan Keterampilan Berpikir Kritis dan Empati Siswa terhadap Lingkungan. Journal of Educational Research and Evaluation, 1(2), 133-138.

Rahmadani, E. 2015. Pengembangan Perangkat Pembelajaran Berbasis Model Discovery Learning untuk Meningkatkan Kemampuan Pemahaman Konsep dan Disposisi Matematis Siswa Berbantuan Geoboard. Tesis. Medan: Universitas Negeri Medan.

Rahmawati, Y., Mardiyana, \& Subanti, S. 2014. Pengembangan Perangkat Pembelajaran Berbasis Penemuan Terbimbing (Guided Discovery) dengan Pendekatan Somatic, Auditory, Visual, Intellectual (SAVI) pada Materi Pokok Peluang Kelas IX SMP Tahun Ajaran 2013/2014. Jurnal Elektronik Pembelajaran Matematika, 2(4), 379-388.

Sugiarti \& Mariantha, I. N. 2017. Pengembangan Model Pembelajaran Discovery Berbasis Kontekstual pada Mata Pelajaran Kimia Sebagai Upaya Menanamkan Sikap Ilmiah Peserta Didik SMA. Jurnal Seminar Nasional LP2M UNM, 2(1), 462-465. Suryani, H. 2016. Pengembangan Perangkat Pembelajaran Disain Busana Berbasis Discovery Learning dan Peningkatan Kreativitas Mahasiswa. Jurnal MEKOM (Media Komunikasi Pendidikan Kejuruan, 3(2), 145-151. 
Chemistry Education Review, Pendidikan Kimia PPs UNM, 2021, Vol. 4, No. 2 (174-189)

Wahyuni, S. 2015. Pengembangan Bahan Ajar IPA untuk Meningkatkan Kemampuan Berpikir Kritis Siswa SMP. Jurnal Materi dan Pembelajaran Fisika, 5(2), 47-52.

Zubaidah, S. 2010. Berpikir Kritis: Kemampuan Berpikir Tingkat Tinggi yang Dapat Dikembangkan melalui Pembelajaran Sains. Malang: Program Pascasarjana Universitas Negeri Malang. 